\title{
The Perspectives of Commercial Property Stakeholders in Post-Disaster Rebuild
}

\author{
Ikenna C. Chukwudumogu ${ }^{1}$ \\ ${ }^{1}$ Department of Property, Business School, University of Auckland, New Zealand \\ Correspondence: Ikenna C. Chukwudumogu. E-mail: ichu564@aucklanduni.ac.nz
}

Received: February 14, 2018

Accepted: March 3, $2018 \quad$ Online Published: April 19, 2018

doi:10.5539/ass.v14n5p82

URL: https://doi.org/10.5539/ass.v14n5p82

\begin{abstract}
This paper seeks to expand our theoretical knowledge on what happens in post-disaster rebuild from the perspective of commercial property stakeholders (investors and developers; agents and professionals). By exploring how they have fared in a post-disaster rebuild environment, this paper has provided a nuanced understanding of the complex challenges they face after a major disaster. This paper adopts an interpretive approach to understanding what it takes to rebuild in a post-disaster environment through the lens and experiences of property stakeholders. After a series of catastrophic earthquakes in 2010 and 2011 in Christchurch, New Zealand, there was consequential damage to most of the commercial buildings in the central business district (CBD). Seven (7) years on, the CBD is still being rebuilt after so much demolition and clearing of debris for an extended period when the city was cordoned off just after the earthquakes. For this study, qualitative data was gathered via semi-structured interviews from twenty (20) purposively identified "Informed Property Stakeholders" involved in post-disaster rebuilding. The interview findings were subjected to an interpretative and thematic analysis used to provide a veracious way of characterising the viewpoints of those interviewed. Overall, this paper has highlighted the perspectives of those interviewed and the findings conveyed that post-disaster rebuilding was an unprecedented and unusual challenge for many property stakeholders.
\end{abstract}

Keywords: post-disaster rebuild, Christchurch, earthquake, property stakeholders, perspectives

\section{Introduction}

This study explores the perceptions of property stakeholders in a post-disaster rebuild environment. Their perspective can be shaped by the interactions of psychological, social, cultural, institutional, political and economic processes at work within the local community (Jackson et al., 2006; McGregor et al., 2008). In 2010 and 2011 a series of earthquakes struck Christchurch, New Zealand (see Figure 1) The disaster resulted in 185 fatalities and more than US\$22 billion of economic losses to the region (CERC, 2012). The damage to properties resulted in a forced evacuation of approximately 7000 property occupiers (Toomey, 2014). Apart from lives lost, the widespread destruction of properties in the CBD was one of the most visible effects of the disaster. Local property stakeholders in the CBD were faced with a challenging decision to rebuild their city which they have gone ahead with. The rebuild of the Christchurch CBD presents a platform to explore their perceptions and experiences. The paper adds to knowledge by expanding our understanding of property stakeholders who represent an integral part of post-disaster rebuilding. To provide context to this paper, key issues examined in the literature review included the earthquakes of 2010 and 2011 in Christchurch, New Zealand and the ongoing CBD post-disaster rebuild; mainstream property investment behaviour; urban regeneration in the context of a property investment and understanding stakeholders' participation in post-disaster rebuild. Subsequently, the research methods and study sample are described. Finally, the interview findings are presented and discussed.

\section{Literature Review}

\subsection{The 2010 and 2011 Earthquakes in Christchurch and the CBD Rebuild}

The city of Christchurch is New Zealand's second largest city and the largest city on the South Island. The Christchurch CBD encompasses approximately 600 hectares and as shown in the figure below is defined by the grid road network bounded by four (4) avenues; Deans, Bealey, Fitzgerald and Moorhouse (see Figure 2). 


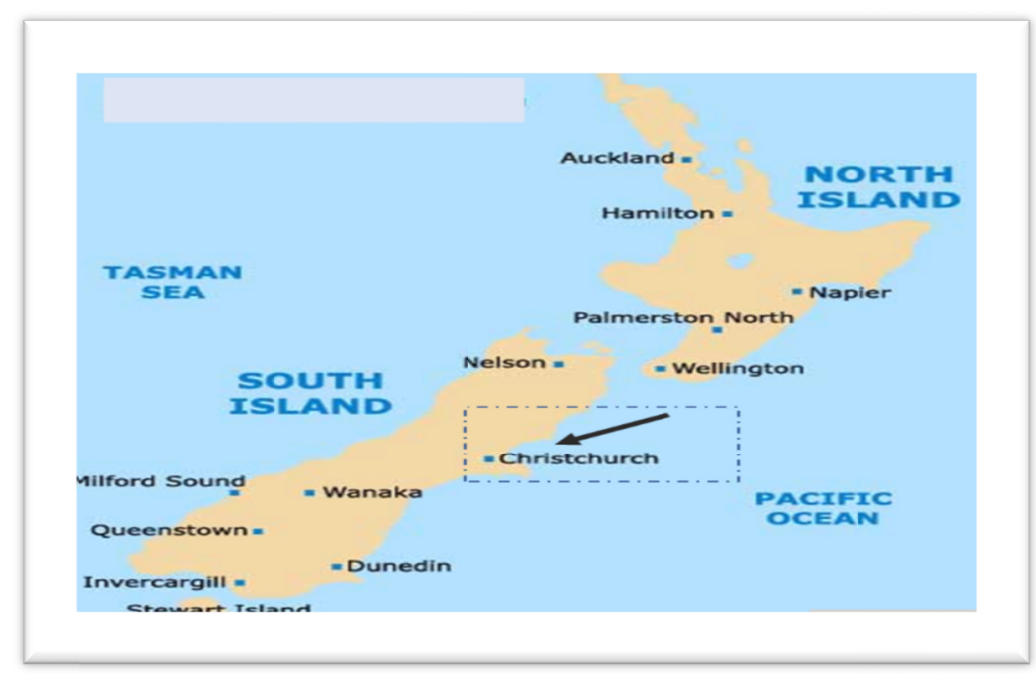

Google Maps (2016)

Figure 1. A Map of New Zealand and Location of Christchurch

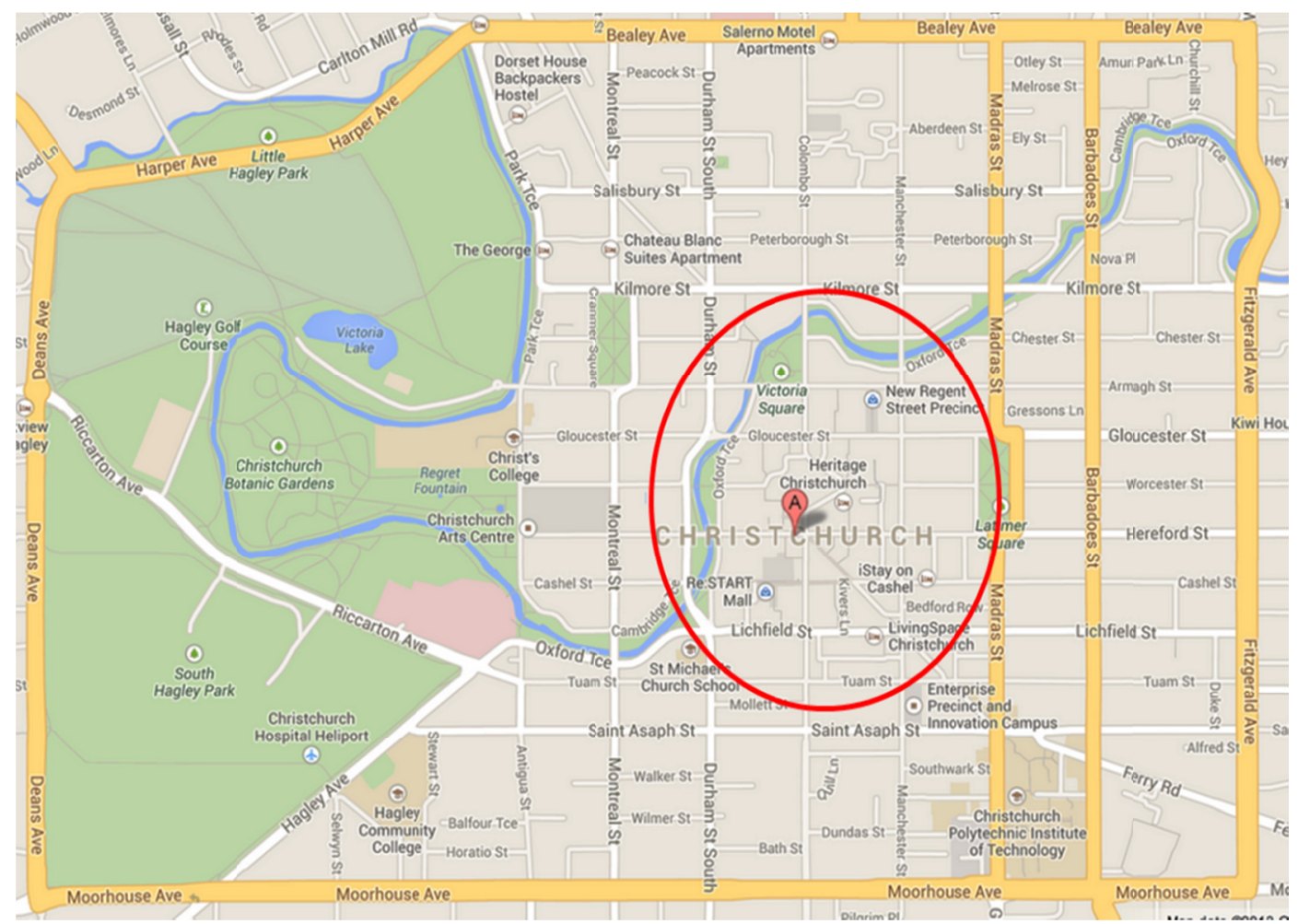

Source: Google Maps (2016)

Figure 2. Map of Christchurch Central Business District

The earthquake events of 2010 and 2011 in Christchurch was a catastrophe of enormous proportions and the New Zealand Treasury estimated the cost of damage at about $10 \%$ of national G.D.P (Bollard \& Ranchhod, 2011). The New Zealand budget policy statement of 2012 stated that the Christchurch rebuilding would, without a doubt, be the biggest economic undertaking in New Zealand's history (Brook 2012). In fact, the New Zealand government did fear for the worst and worried that the second biggest city in the country might simply implode from the shock (McCrone, 2014). But the city was well insured and the local economy did not entirely collapse as initially feared (Brown et al., 2013). This advantage was attributed to the fact that New Zealand has one of the highest insurance penetration rates in the world (Brown, Seville, \& Vargo 2013; CBRE, 2012). The government 
declared a state of national emergency and Civil Defence became lead agency, with a cordon established around the CBD area. Chang et al., (2011) provide a detailed description of the impacts of the CBD cordon which had been reduced to about half its original size by July 2011 and removed entirely in June 2013. It is important to note that after a major disaster, there were profound changes in the CBD and this was manifested in the over $90 \%$ of the office space stock lost due to the earthquakes (Moricz et al., 2012; Anthony, 2014; Sellars, 2013).

\subsection{Mainstream Property Investment Behaviour}

The literature on property investment market behaviour often reflects rational, normative models that treat behaviour as highly structured and formalised (Galimore et al., 2000). The bulk of literature in this regard is positioned within the standard assumption of mainstream or neo-classical economics (Ohman et al., 2013). This idea is based on the rationale that decision makers with stable preferences are acting in a perfect market with many competitors, accessible information and homogenous products. The practices of property stakeholders are most times based on these conventional assumptions, which consists of paradigms inherited from both economics and finance disciplines (Diaz III, 1999). A majority of this type of literature on the property investment market according to Diaz III, (1999, p. 327) are "...theoretically underpinned by the rational man construct and the efficient market hypothesis and uses regression-based econometric techniques..." to analyse price and quantity. By contrast, behavioural psychology suggests that individuals can act sub-optimally and this is often a neglected aspect in the property literature. The post-disaster rebuild environment is perceived as dynamic and quite chaotic. Therefore, the actions of property stakeholders are not entirely rational and will be subject to heuristics, sentiments and biases. The property market comprises a network of actors with unique roles and distinct economic behaviours in different circumstances depending on their organisational objectives (Ball, 2006 and 2010). The behavioural examination can provide a harmonising effect on other theoretical approaches adopted in property research.

\subsection{Property Investment Behaviour in Urban Regeneration}

This paper has adopted a premise that urban regeneration and post-disaster rebuilding presents similar conditions to property stakeholders. Conceptually, urban regeneration is a process of reversing economic, social and physical decay in towns and cities where market forces alone will not suffice (Adair et al., 1999). It entails the perception of a declining inner-city that incorporates a process of physical regeneration to establish a basis for economic growth and social well-being (Healey et al., 1992). An integral part of the urban regeneration literature involves understanding the perception and role of the property stakeholders concerning stimulating re-investment and re-development after a major decline. Studies by McGreal et al., (2000), Adair et al., (1998 and 2003) and Nappi-Choulet, (2006) indicate that perceived total investment returns remain a primary influence on property investment and development decisions. In a similar vein, Nappi-Choulet (2006) also found that the involvement of institutional property developers in the urban regeneration of the Paris region of France was dependent on their ability to attain high returns on investment and that the internal rate of return (IRR) was the main criteria for investment decision-making. This influence is due to the requirement of above-average returns on investments necessary for addressing viability concerns.

Adair et al., (1998 and 2002), emphasised that private sector investment is opportunity driven and needs to show returns commensurate with the risk and return profile of participants. Therefore, efficient and a receptive property market is essential to lever investment into urban regeneration locations. Adair et al., (1998), also highlights that typical institutional investors set very high criteria for compensating risks when considering any investment in urban regeneration location due to higher uncertainty. This perception translates into the demand for a higher risk premium reflecting the seemingly poorer physical and locational characteristics of many urban regeneration areas. Consequently, there is a psychological preference for safer investment choices perpetuates certain misconceptions about urban regeneration areas such as low returns, weak demand and high costs Adair et al., (1998 and 2002). There may be some downsides to these perceptions because by placing too much emphasis on the prospects of financial viability, investors may miss any potential investment opportunity that may come from urban regeneration locations. In a final analysis, Nappi-Choulet, (2006); Tranch and Green (2001), believe smaller local investors have the advantage of intimate knowledge of the property market and close relationship with local authorities.

\subsection{Stakeholders Participation in Post-Disaster Rebuild}

A better understanding of disaster rebuilding can be achieved through practices that understand the dynamics of stakeholders via socio-economic restructuring (Waugh \& Smith, 2006; Ishihara, 2007; McGee, 2008; Ruwanpura, 2009) and urban regeneration (Comerio, 1998; Kamel \& Loukaitou-Sideris, 2004; Olshansky et al., 2006; Dercon, 2007). The collective challenge is for stakeholders to learn and minimise the likelihood of making 
mistakes in future disasters. The participation of property stakeholders is critical in post-disaster rebuild, but there is a somewhat limited scope on their perceptions. A more in-depth understanding of these dynamics can lead to more targeted and prompt intervention in post-disaster recovery. The participation of stakeholders in post-disaster reconstruction helps create a shared understanding of local hazard risk and vulnerability, improves recovery and mitigation decisions, builds social capital and local resilience to future disasters (Godschalk, 2003; Jones, 2003; Olshansky et al., 2006).

Chandrasekhar, (2012) underscored the stakeholder theory from the perspective of organisational behaviour and strategic management as a means of identifying the perceptions of stakeholders in post-disaster planning and actions. Mitchell, Agle, and Wood (1997, p. 853) employ three attributes to describe stakeholders and their prominence in organisational decision-making: power (the extent a party has means to impose its will), legitimacy (mutual recognition due to conforming with expected norms), and urgency (time sensitivity of stakeholder's claims). Although developed to explain the dynamics of organisational decision-making, the stakeholder theory can be applied to other decision-making processes as well. In a nutshell, identifiable factors such as power, legitimacy, trust, and urgency of action may influence the level and manner of stakeholder participation in post-disaster recovery. Stakeholders are continuously negotiating their power; building trust; actively gaining legitimacy and having a sense of urgency in a post-disaster environment. An important question that arise from this study was who are the key stakeholders in post-disaster rebuilding? A developed framework on the post-disaster environment (see Figure 3) was useful in answering this question. It showed how commercial property stakeholders in a network of post-disaster recovery actors were the focus for this paper considering the rebuilding was in the commercial heart of the city centre (CBD).

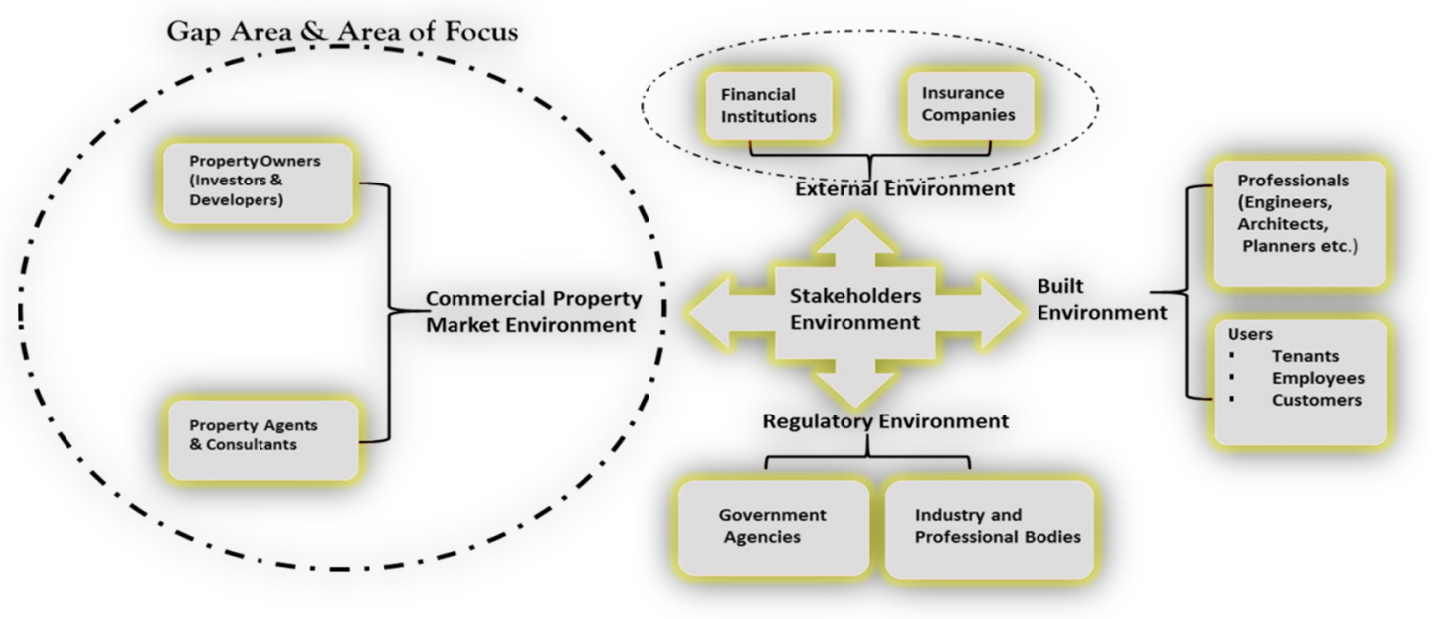

Figure 3. Stakeholders in a Post-Disaster Environment

\section{Research Method}

To achieve a goal of this paper which was to build on theory without testing any preconceived hypothesis, a qualitative and case study methodology was adopted to search for a more in-depth meaning and understanding (Goulding, 1998). The findings from this study are not intended to be generalised to a broader population but can provide a theory for future testing. A theoretical sampling technique was adopted to construct theory by identifying mid-level themes from the interview findings. This method entailed a grounded theory inductive approach allowing the data to tell the story and to generate theories and concepts systematically.

The target interview sample for this research were commercial property stakeholders engaged in rebuilding. They were selected based on their ability to provide the information being sought. Judgemental sampling was used to identify participants most appropriate for this study. This approach entails a choice of subjects who are in the best position to provide the information required (Cavana et al., 2001; Churchill \& Iacobucci, 2002). The interview participants were selected based on their knowledge, experience and active participation in the Christchurch CBD rebuild. They comprised diverse participants used as the primary unit of analysis. All interviewees had first-hand experiences of the 2010 and 2011 earthquakes and well informed of all that has transpired in the CBD rebuild.

According to Yin, (2003), the knowledge and experience of respondents are essential because only a 
well-informed respondent can provide salient insights into the questions being investigated. Creswell (2003), explains that the idea behind a qualitative study is to diligently select participants that will best help the investigator understand the problem and the research questions. The research methods were exploratory and carried out via direct encounters with people to gain an in-depth understanding of the underlying perceptions and reasoning of study participants.

Table 1. Categorisation of Interviewees $(\mathrm{n}=20)$

\begin{tabular}{|c|c|}
\hline Interviewee Codes & Interviewee Categories $n=20$ \\
\hline \multicolumn{2}{|c|}{ Category 1: Public sector (CCDU, CERA \& City Council). $n=2$} \\
\hline C\&L 1 & Senior management employee at Christchurch city development unit (CCDU) \\
\hline C\&L 2 & Senior management employee at local council \\
\hline \multicolumn{2}{|c|}{ Category 2: Property Agents/Consultants/Advisors. $n=3$} \\
\hline P.A 1 & $\begin{array}{l}\text { Director of research and strategic planning for an internationally recognized property consultancy firm } \\
\text { with a local base in Christchurch. }\end{array}$ \\
\hline P.A 2 & $\begin{array}{l}\text { Director of retail for an internationally recognised property consultancy firm with a local base in } \\
\text { Christchurch. }\end{array}$ \\
\hline P.A 3 & $\begin{array}{l}\text { Senior manager office leasing for an internationally recognised property consultancy firm with a local } \\
\text { base in Christchurch. }\end{array}$ \\
\hline \multicolumn{2}{|c|}{ Category 2: Property Owners (Investors and Developers) $n=14$} \\
\hline PID 1 & Private investor and developer/businessman \\
\hline PID 2 & Private investor and developer \\
\hline PID 3 & Development manager for a regional property investment company \\
\hline PID 4 & Property manager for a local property Investment company \\
\hline PID 5 & Private investor and developer \\
\hline PID 6 & Private investor and developer \\
\hline PID 7 & Private investor and developer \\
\hline PID 8 & Private investor and developer \\
\hline PID 9 & Private investor and developer \\
\hline PID 10 & Private investor and developer \\
\hline PID 11 & Private investor and developer \\
\hline PID 12 & Private investor and developer \\
\hline PID 13 & Private investor and developer \\
\hline PID 14 & Private investor and developer \\
\hline \multicolumn{2}{|c|}{ Category 4: Financing and Lending $n=1$} \\
\hline F\&L 1 & Commercial property finance manager for one of the biggest banks in New Zealand. \\
\hline
\end{tabular}

As shown in Table 1, twenty (20) "Informed Property stakeholders" who are involved in the on-going CBD rebuild were purposively identified for the interviews. In order to achieve the objective, the interviewees were recruited from three (3) categories, namely; i. Public sector $(\mathrm{n}=2)$, including policymakers who were senior ranking staff in the local council and government agencies; ii. Property consultants $(n=3)$, comprising senior management staff of high profile property consultancy firms; iii. Property owners $(n=14)$, comprising mostly local property investors and developers who are deeply involved in the city rebuild with large scale property developments; iv. Finance and lending institution $(\mathrm{n}=1)$, which included a major commercial bank in New Zealand. This categorisation encompassed the main property stakeholders who were actively engaged in the city rebuild and had extensive knowledge of the commercial property industry.

The semi-structured interviews questions comprised three sections. The first section entailed broad questions on their background and their experience in Christchurch property market. The second section was designed to elicit a response on their perspectives on the CBD rebuild and the third was to understand the nature of their role in the process. The idea was to get as much information as possible based on their actual experiences. In this regard, an interview guide was also formulated before the interviews to address the general areas of interest and particular questions around the topic. The interview process entailed guiding the interviewee through the questions, listening and following up with additional questions where there were ambiguities. The number of the interviews 
carried out was not specified at the onset and each interview lasted for at least an hour. The final number of interviews was determined when the outcome from subsequent interviews became repetitive and no new themes emerged and this according to (Carson et al., 2001) is when the research becomes saturated with information. The interviews were carried out from mid-2017 until the end of 2017. All interviews were audio recorded, transcribed into about a hundred pages of raw text. The transcripts were analysed thematically resulting in the development of themes or patterns about the subject under study. A series of themes derived from the interviews were then elaborated upon, supported by quotes from the interviews. These themes described the ways these property stakeholders interpreted the post-disaster rebuilding and how their interpretations have led to particular sets of responses and actions.

\section{Results: Themes from Interviews}

Those interviewed displayed very complex and contextually grounded perspectives on the post-disaster rebuild. Overall, their perceptions were infused with strong elements of sentiments and emotions. The main themes identified are discussed under the following headings.

i. The role and actions of government.

ii. The role and actions of property owners.

iii. State of shock, risk and uncertainty

iv. General perceptions on the post-disaster rebuild in the CBD.

v. Drivers and Motivation to Rebuild

\subsection{The Roles and Actions of Government}

Just like any other major disaster that happens in around the world, the government comes in to play a vital role of ensuring public safety and security. Their actions were primarily to bring some level of confidence and certainty among other stakeholders who would engage in the post-disaster rebuild. As regards the CBD, compelling and sometimes controversial decisions were taken over the course of the rebuild by all levels of the New Zealand government. Some of these actions by the government included; cordoning the central business district; residential zoning; creation of the Canterbury Earthquake Recovery Authority (CERA) and Christchurch Central Development Unit (CCDU); developing of the Christchurch central recovery plan also known as "The Blueprint". The Canterbury Earthquake Recovery Authority (CERA) was the agency established by the Government to lead and coordinate the entire recovery effort in Christchurch. The Christchurch Central Development Unit (CCDU) was established to help renew the CBD by looking after commercial developments in line with the new CBD blueprint and also significantly shrinking the size of the CBD. In the words of C\&L 1

"The key thing that needs to be done in this situation of uncertainty was to provide certainty. So the Crown committing to deliver key aspects of the Blueprint that being the anchor projects was really vital."

Another interviewee C\&L 2 also stressed that

“... Confidence was the currency of the day and still is and we would have done a lot better by making sure we had on time delivery of key assets."

The government had very high expectations on how the new CBD would be but had no plans to fully fund them, thereby having to rely on private investments on some of the projects. Generally, the interview findings showed a lot of pessimistic view on the role and actions of the government after the earthquakes. The general feedback was that the government bureaucrats have not enabled private people who are doing most of the rebuilding. The government have focused more on the internal process and implementing regulations and plans that are sometimes not helpful to property owners. Even (C\&L 2) confirmed this by saying

"The government agencies did not deal with the property owners in confidence as regards communicating their plans for the city. I think that should have been approached differently."

This was also a general opinion across all section of those interviewed. In fact, one of the property consultant, P.A 1, expressed an extreme level of antipathy and frustration with some of the ideas in the new blueprint for the CBD. In his words,

"After the earthquakes, for mostly political reasons, a rebuild plan was hastily rushed through in 100 days. Unfortunately, there were no loud commercial property voices at the conception which is regrettable and ironic because we were talking about rebuilding the central business district. Originally, commercial property experts were not consulted to advice during the initial preparation of the central city blueprint plan. Specifically, there were little or no advice on the commercial viability prospects of new property development that would take place 
in the new CBD."

The interview findings also showed that this was not really not considered a surprise because after the earthquakes, there were a lot of expectations that led to a quick rush to develop a plan that calmed the nerves of local people because the government wasn't ready to tell people that the post-disaster rebuild will take many years. But most property developers and investors who are key players in rebuilding the new CBD are also concerned about development costs and commercial viability. Another interviewee PID.3 also criticised the actions of government, he mentioned that;

"In my experience the government at all levels have been very slow, over regulated with no vision and no leadership. The whole central city rebuild has been handled very poorly because most of the private investors and developers have not delivered on their projects due to the failure of the public-sector led projects to start."

The completion of the public-sector led projects is critical to the success of the CBD rebuild. The interviewees from the public-sector agencies also shared a similar frustration as to what was going on. Many of the government bureaucrats never had any real authority to take important decisions because they had to wait for final approval from local politicians. In the words of C\&L 2

"A lot of it is the internal processes inside CERA/CCDU and around the feasibility and planning stages. I also personally believe it is due to the insufficient communication outside the organisation to key interest and stakeholder group. We very much have a thing called "fortress CERA" so we contain information and only release information when it is absolute and finalised". "At the moment we only have 10\% of the anchor projects that have met their time-lines while the remaining are wither still in the process (i.e. missed their time-lines for completion) or haven't commenced at all. For example, the convention centre."

There is still an absence of certainty on a lot of what is going to happen regarding the public-sector led projects such as the convention centre, which is having a negative impact on the confidence of property developers. Some of the frustration on the actions of the government has also been around the incompetency of some of those who worked. The feeling was that some of these public entities were hastily established and they just picked up anyone that was available to be part of the workforce. There have also being the issue of too many government agencies who at times didn't get on well taking part in the city rebuild. But there are hopes that with the new changes to the government bodies, there will be some improvements.

\subsection{The Role and Actions of Property Owners}

It was obvious from the findings that the Christchurch earthquakes had profoundly transformed the role of affected property owners. They had to take on new functions and acquire new knowledge and skills in order to remain competitive in a post-disaster environment. Some property owners cashed out on their insurance pay-outs and walked away from the city to invest elsewhere, while many have stayed back to be part of the new CBD rebuild. The interviews findings also showed that the property owners took the initiative and driving the CBD rebuild because they believe they have more at stake. Interviewees C\&L 1 confirmed this by saying

"Our analysis has shown that a majority of the investment money in the rebuild of the central city has so far come from Christchurch."

The reason for this according to him was that,

"People invest somewhere or in something that you know the background and details and somewhere you are generally comfortable around the hometown or a business you have been involved with before. In other words, Christchurch people know and understand the Christchurch property market."

Furthermore, P.A 1 also confirmed that

"A lot of Mum and Pop business people have overnight become property developers because they lost everything they had to the earthquakes and have been forced to develop."

The expectation and championing of foreign investment coming in to the rebuild by the public- sector was in the words of interviewee PID 4 "just wishful thinking". There was also the issue of speculative behaviour ("wait and see") at the early stages of the CBD rebuild among property owners. This was due to the uncertainty as to what was really going to happen with the city. An interviewee C\&L 3 highlighted that

"One of the very big-scale developers in the town just started building without any tenant commitment. But he has now taken it upon himself to search for tenants and he is already succeeding in that area. Generally, for most of them, it is a big transition and they are making it work."

Property owners rebuilding had to transition from investors into active property developers without adequate 
knowledge of the field. They typically had no experience in the property development process and in some instances, they have struggled to cope with the transition to new roles. Even though they were well financed to rebuild, they spent much more than necessary on cost overheads from over-engineered building designs due to a lack of development experience. They had not fully appreciated the difficulty of undertaking commercial property developments by not quantifying the unfamiliar risks and uncertainties in a post-disaster environment. Two interviewees who were financial lenders explained this transformation by property owners affected by the earthquakes saying:

These guys were historically investors not developers. Generally, for most of them, it is a big transition and they are making it work. ( $C \& L 1)$

...some of them didn't know what they were getting themselves in for. Some got half way through their projects and said "WOW", that is too much risk, too hard and they have tried to step back and exit such developments.

$(C \& L 2)$

A well-known local property agent and consultant also summarised this point by saying:

A lot of these people were mainly property investors not developers. They generally bought existing buildings and held them as investments. Then suddenly after the earthquakes they had vacant land and huge insurance pay-outs. So they had to learn how to be developers, most of them are first-timers and haven't done it particularly well. They did not seek proper advice on what kind of tenants were in the market, what they wanted and what kind of thing they should be building. (P.A 3)

In general, these comments depict the sort of transformation that many property owners have gone through over time. The prevailing thoughts among property owners according to PID 1 was that

"Let's build them and the tenants will come. But this never applied to the central city rebuild."

But at the same time, he mentioned that

"We understood that no tenant would be willing to commit to anything unless they saw something going on."

Local knowledge of how the city works was key in order to navigate some of the challenges. Interviewee PID 4 also mentioned that;

"For us, the first 2-3yrs after the earthquakes It has been a very busy and frantic time because of the complexity of everything we have been doing from settling with insurance companies to assessing damages, satisfying tenants that the building are fixed, dealing with a whole range of engineers and other consultants and off course building new buildings. A lot of energy has gone into relationship management with the insurance companies and in terms of getting the right pay-outs and agreement and also getting continued insurance covers on some of our commercial buildings at reasonable premiums and terms and conditions. We had a very strong adversarial role in dealing with insurance companies. It was difficult to get an agreement between the consultants of engineers as to what the severity of damage had been."

A significant number of those property owners rebuilding used to be just investors with no skills in property development. Due to the large sums of insurance pay-outs received, a lot of them are not very motivated to develop buildings efficiently and so it is a learning curve for a lot of people. These individuals originally owned and, in some cases, bought several properties before the earthquakes for investment purpose and the earthquake disaster has forced them to replace their lost buildings and cash flow. According to PID 3

"We have been passive investors who have felt the need to rebuild an asset on the same site as way of getting the rent from their investment. We have also underestimated the difficulty of finding tenants for the building. We haven't really thought about the demand side. We basically had a site and got some insurance pay out to build. As a result, some of the normal constraints of supply and demand on the issue of commercial feasibility haven't been well assessed. We have been left disappointed because of the complexity of developing and inexperience. So that is the sort of shake down they would continue to go through over the next few years."

An interviewee with a lot of experience in financing commercial developments (F\&L 1) prior to the earthquake disaster also highlighted that

"In part, some of those undertaking developments are not professionals, they are more of business people who have gone into property development. They don't have proper development management skills and, in my view, don't manage their projects well enough. As a result, their cost base is higher than what I think it should be and they don't manage their Architects well enough. Or they have a building which is very extravagant."

In summary, the bulk of post-disaster rebuilding are being carried out by the local people. Adjusting and adapting 
to the rebuilding of a CBD after a major earthquake has been a strenuous experience for many of those interviewed. This has resulted in many property owners experiencing the difficulty of property development for the first time because it is a completely new role for many of them. Despite the challenges, they have moved forward to take on the unfamiliarity of a post-disaster environment by reinvesting in CBD.

\subsection{State of Shock, Risk and Uncertainty}

All those interviewed were unequivocal in expressing their state of shock after the fatal earthquake of 2010 and 2011. For most, it was a state of denial on the extent of damage that occurred in the city. Many parts of the CBD were cordoned off for nearly two years immediately after the earthquakes and over a thousand (1000) commercial buildings had to be partially or completely demolished and cleared during this period. At the early-stages, there was a lot of uncertainty as to what was going to happen next due to the length of time it took the government to effectively articulate and communicate their plans for the CBD to affected property owners. A majority of property owners interviewed were still recovering from the shock they experienced over six (6) years ago. It is also important to note that this state of shock has gradually diminished over time as intense rebuilding works started going on. In the words of PID 5

"The central city rebuild is starting to take shape but still has a long way to go. I think right now we are past the phase where the concern was that will the city ever recover."

Overall, this was a general consensus from all of the interviewees. This traumatic experience was succinctly expressed by a prominent local property investor and developer PID 1

"I used to have 12 buildings in the central city and then suddenly I had none left after the earthquakes. This was quite a significant and traumatic change for me. I also used to have a hotel and two (2) restaurants which I personally ran myself with forty (40) staff. But after the earthquakes, I only had one (1) staff. It was quite a significant change."

Additionally, in the words of PID 2

"I spent the first 2yrs after the earthquakes knocking down buildings. We had 70 buildings we managed in the $C B D$, which were all demolished. What we did for the first $2 y r s$ was basically to go to the insurance companies to negotiate on behalf of our clients and organise for buildings to be demolished."

For property agents and consultants, the period immediately after the earthquakes saw a surge in activities like never seen in Christchurch. Most big tenants that were in the city before the earthquakes took on medium to long term leases to relocate to the suburbs of Christchurch. Some of the leases where quite expensive and still running. For P.A 3,

"The period immediately after the earthquakes was a juggling act. We enjoyed a surge in office leasing by assisting affected businesses and tenants who were desperate relocate to suburban locations."

Due to the level of uncertainty around, there were some property investors and developers who simply stayed out of what they described as a mess until there was a clearer picture of what was going to happen to the CBD. This was the view of one of the interviewees PID 5 who said

"Immediately after the earthquakes, because there was so much uncertainty in terms of how our city was going to evolve. My business partner and I went out to the Rangiora area (suburbs) to build a new development for the ministry of social development who was one of our tenants. So, we did the building because we got a tenant out for it in New Brighton. So, this took us 18months and then after that time things became a bit clearer as to how the central city was going to develop. Then we had a good look around and in this current area we are move ahead quietly with development because there no cordons in the area."

In addition, another interviewee PID 4 also mentioned that

"We have been developing but we made a decision to stay out of the CBD because we had projects outside the $C B D$. Even though we owned properties in the $C B D$, we were not doing any new developments at the time. So when the earthquakes came, we focused on finishing our suburban jobs worth about \$20million. We focused on suburban locations, because we just we thought that the CBD was going to take many years to re-initialise what was going to happen. One of our big building in the CBD prior to the earthquakes was acquired by CERA for one of the anchor projects. We probably would have started a new project on it if we retained the land."

For many of those involved in rebuilding the CBD, they are taking on unfamiliar challenges and risks. For example, property investors and developers are first timers and don't really appreciate what it takes to succeed. As a result, there are potentials for huge losses or gains regarding some new redevelopments. Some of the challenges raised in many of the interviews included negotiating insurance pay-outs, a lack of access to the inner 
city for two years, knowledge of how to transition from property investors to full time developers and incorporating their property development aspirations with government plans for the CBD. The interview findings identified present and future risks in the CBD rebuild to include concerns around the financially viability of new developments; will tenants take up the new spaces at a reasonable rent level? Is the increased cost of building to new standards affordable?

\subsection{General Perceptions on the Post-Disaster Rebuild in the CBD}

The responses from most of the interviewees was that of mixed feelings as to what could and should have been done. There is still resentment on the part of some the property owners affected by the compulsory land acquisition which took place after the earthquakes. So far, there have been winners and losers, but many property investors and developers have just forged ahead with the rebuild. Due to the protracted nature of the rebuild, there have been some level of frustrating among those that were interviewed. The timelines for a lot of the new developments has taken much longer and as a result we have a sort of stagnation of the inner city because things appear very slow. According to PID 6 and 7

"The rebuild is now beginning to get some traction because some private developers have gotten off their back and built new buildings and office block which will need support from the retail environment and now the retail developers are getting some comfort in developing. So, there is still some uncertainty in certain parts of the city due to the slow and disjointed nature of the central city rebuild."

"Basically, I think that the politicians and people that have been involved with the rebuild have done their very best with the information and knowledge they had."

All property investors and developers interviewed felt the CBD rebuild was a prime opportunity to create something way better than the city ever had ever had before. In the words of PID 8

"I believe we needed a paradigm shift in thinking. I believe we had one chance in history to recreate something different and amazing and we could have taking the opportunity. I think what we have done is to go back to the norm because it was easier. One of the things I suggested to the government was to set up or consider special economic zone which is a common practice all over the world. This would have taken an area in difficulty like Christchurch was and do something very different and radical. What was suggested was to create a tax-free zone for 10yrs for every person who lived and worked in the zone. If that was in place, there would have been a sudden rush by people to come, live and build and develop in there because they had got loyrs to pay no taxes i.e. would have been a great stimulus to the city centre rebuild. I believed the idea would have worked and I talked to several politicians who acknowledged it but said the government could not afford it."

The reality is that the city is being built up by mainly locals who were property owners in Christchurch before the earthquakes. Almost all the big developments in the new retail precinct of the CBD are being done by locals and there are only about half a dozen names. PID 13 referred to the CBD rebuild as "painstakingly slow and cautious". The findings also indicated that many have forged ahead and for some of those rebuilding it has worked out very well. The cordoning of parts of the CBD for a long period of time, allowed some property developers to take advantage of the locations that were not cordoned off around the city to start re-building early and have profited from it by getting a head start in picking prime locations for the new CBD. Some of those rebuilding did not understand the risks they needed to quantify earlier on or have taken on more risks than anticipated. According to PID 11,

"For those that were historically investors, some of them didn't know what they were letting themselves in for. Some got half way through their projects and said 'WOW', that is too much risk, too hard and they have tried to step back or exit such developments. In some instances, they have been successful at getting out of them while some of them are still stuck".

At the early start of the rebuild, there were those who decided to stay out of the CBD rebuild due to the uncertainty. PID 6 said

"We focused on suburban locations. Because we just we thought that the CBD was going to take many years to re-initialise what was going to happen."

The CBD rebuild is happening slowly but surely. The private sector has picked up and really got things going. It is a little unfortunate that the government have been slow in confirming some of the public-sector led projects like the convention centre.

\subsection{Drivers and Motivation to Rebuild}

The CBD rebuild in Christchurch is being driven by local people who generally received large insurance 
pay-outs considered as free money to replace their old buildings. So, if you are an outside investor you don't have the advantage of insurance money and don't know how the dynamics of the city has changed and a result could easily build in the wrong place.

Many of those rebuilding the CBD were driven by a passion for the city. This was quite unusual because property investors are ideally more attracted to a stable investment environment. Although, some property owners have cashed up on everything they had and walked away, many stayed back to rebuild the CBD. Those who are rebuilding are sentimentally attached to the city. According to one of those interviewed, PID 1 hinted that

"If you look at the private developments in the precinct I am in, they are mostly Christchurch locals. Suddenly, you are looking at locals. There are no Aucklanders, Singaporean, and Chinese. Everyone thought they would come but it didn't happen. So, without the local Christchurch city centre will be a desert".

He further stated that

"We are "passionate" about the city and it is that passion that is driving us. If it were just financially, I wouldn't be involved in the rebuild, because it makes no sense. It is more of a "Passion" for the city."

The parochial and patriotic attributes of the local people was a key driver for rebuilding. C\&L 2 explains them

“... as those who don't want to re-invest their money in other places because they don't know those places well. They are concerned about the risk of investing in a domain they don't know well enough and they can't see every day. So, the main reason why people are investing here is because they are from here and they have always invested here and they don't see themselves investing somewhere else as something they are comfortable with in terms of risk and knowledge."

Many property owners interviewed received large insurance pay-outs which varied depending on the number of properties they owned before the earthquakes and the robustness of their insurance cover. The findings from the interviews revealed that the bulk of private rebuilding in the CBD have been financed by these insurance pay-outs. They were paid full reinstatement value for their lost properties, which also came with conditions of committing to rebuild. These affected property owners utilised their insurance pay-outs to replace their destroyed buildings with new and superior ones. Although the funding for most of the private rebuilding in the new central city has come from multiple sources, insurance pay-outs were a key source of financing that has initiated the rebuilding at the early-stages. These property owners understood that the post-disaster rebuild was going to be a very expensive project that would rely heavily on their private finance and investment. A property investor and developer confirmed that the progress with rebuilding has been attributable to the significant financial support from insurance pay-outs. He stated:

A lot of what is happening now in terms of new commercial developments is as a result of insurance money. Without it, we would not be seeing more than half of what is going on now. (PID 8)

It was the view of most stakeholders interviewed that the early expectation of international investments coming into the Christchurch CBD rebuild was just political theatre which never happened.

\section{Conclusion}

This paper has taken a behavioural perspective to interpret how human sensibilities have triggered a grounded pattern of behaviour among commercial property stakeholders involved in the post-disaster rebuild of Christchurch CBD. It has fleshed out how they perceive the rebuilding process. The qualitative study design adopted has enabled an in-depth understanding of the underlying factors shaping their perceptions of the post-disaster rebuild. The goal of this paper was to report and put into context the viewpoints of sampled commercial property stakeholders engaged in post-disaster rebuilding. Although normative assumptions provide an "ideal world" view of property investment, the chaotic nature of the post-disaster environment appears to preclude any form of rational actions by property stakeholders. Those interviewed have engaged in post-disaster rebuilding with limited information, unusual risks and uncertainties. Generally, they viewed their actions in the CBD rebuild as a commitment to their own city. In a nutshell, the evidence suggests that their perceptions are moulded mainly by sentimental commitments to the city. In a broad sense, they expect to satisfy their personal objectives, which may not be formulated in analytical terms.

\section{References}

Anthony, K. (2014). Christchurch office market: There and back again. CBRE

Ball, M. (2006). Markets \& Institutions in Real Estate \& Construction: RICS. 
Ball, M. (2010). Critical commentary. Cities and housing markets: Changes and continuities in the aftermath of the 2007-08 World Financial Crisis. Urban Studies, 47(5), 931- 944. https://doi.org/10.1177/004209801036 4143

Brook, A. M. (2012). Making fiscal policy more stabilising in the next upturn: Challenges and policy options. New Zealand Economic Papers, 47(1), 71-94. https://doi.org/10.1080/00779954.2012.721691

Brown, C., Seville, E., \& Vargo, J. (2013). The role of insurance in organisational recovery following The 2010 and 2011 Canterbury earthquakes (Research No. 2013/04). University of Canterbury: Resilient Organisations.

Canterbury Earthquake Recovery Authority (CERA). (2012). Amendments to Christchurch City Council's District Plan. Updated in July 2013. Christchurch: Canterbury Earthquake Recovery Authority. Retrieved March 27, 2015, from http://cera.govt.nz/maps

Canterbury Earthquakes Royal Commission (CERC). (2012). The performance of Christchurch CBD buildings (Final Report, Volume 2). Retrieved June 24, 2014, from http://canterbury.royalcommission.govt.nz/vwlu Resources/FinalReportVol2Print/\$file/Final_Report_Volume_2_Web.pdf

Carson, D., Gilmore, A., Perry, C., \& Gronhaug, K. (2001). Qualitative Marketing Research. Sage Publications, London. https://doi.org/10.4135/9781849209625

Cavana, R. Y., Delahaye, B. L., \& Sekaran, U. (2001). Applied business research: Qualitative and quantitative methods. John Wiley \& Sons Australia.

Chandrasekhar, D. (2012). Digging Deeper: Participation and Non-Participation in Post-Disaster Community Recovery. Community Development, 43(5), 614-629. https://doi.org/10.1080/15575330.2012.730538

Chang, Y., Wilkinson, S., Brunsdon, D., Seville, E., \& Potangaroa, R. (2011). An integrated approach: Managing resources for post-disaster reconstruction. Disasters, 35(4), 739-765.

Churchill, G., \& Iacobucci, D. (2002). Marketing Research, Methodological Foundations (8th ed.). London. Harcourt Publishing.

Comerio, M. C. (1998). Disaster Hits Home: New Policy for Urban Housing Recovery. University of California Press, Berkeley and Los Angeles, California.

Creswell, J. W. (2003). Research Design: Qualitative, Quantitative, and Mixed Methods Approaches (2nd ed.) SAGE, Thousands Oaks, California.

De Bruin, A., \& Flint-Hartle, S. (2003). A Bounded Rationality Framework for Property Investment Behaviour. Journal of Property Valuation \& Investment, 21(3). https://doi.org/10.1108/14635780310481685

Dercon, B. (2007). Two years of settlement recovery in Aceh and Nias: What should the planners have learned? 43rd ISOCARP Congress 'Urban Trialogues - Co-productive ways to relate visioning and strategic urban projects'. Antwerp, Belgium.

Diaz III, J. (1999). The first decade of behavioural research in the discipline of property Journal of property investment \& finance, 17(4), 326-332. https://doi.org/10.1108/14635789910271728

Godschalk, D. R. (2003). Urban hazard mitigation: Creating resilient cities. Natural Hazards Review, $136-143$. https://doi.org/10.1061/(ASCE)1527-6988(2003)4:3(136)

Google Maps. (2016). The Christchurch Central Business District. Retrieved November 24, 2016, from https:/www.google.co.nz/maps/place/Christchurch/@43.520185,172.640417,14.04z/data=!4m5!3m4!1s0x6 d322f4863c5ed01:0x500ef8684799945!8m2!3d-43.5320544!4d172.6362254

Goulding, C. (1998). Grounded theory: the missing methodology on the interpretivist agenda. Qualitative Market Research: An International Journal, 1, 50-57. https://doi.org/10.1108/13522759810197587

Ishihara, Y. (2007). Indonesia: Economic and Social Update. The World Bank Country Update. Jakarta. The World Bank. Jain, S. K., and N. C. N

Jackson, J., Allum, N., \& Gaskell, G. (2006). Bridging levels of analysis in risk perception research: The case of the fear of crime.

Jones, R. (2003). An environmental risk assessment/management framework for climate change impact assessments. Natural Hazards, 23, 197-230. https://doi.org/10.1023/A:1011148019213

Kamel, N. M. O., \& Loukaitou-Sideris, A. (2004). Residential assistance and recovery following the Northridge 
Earthquake. Urban Studies, 41(3), 533-562. https://doi.org/10.1080/0042098042000178672

Marquis, F. (2015). A framework for understanding post-earthquake decisions on multi-storey concrete buildings in Christchurch, New Zealand (Doctoral dissertation). University of British Columbia (Vancouver).

McCrone, J. (2014). Christchurch rebuild: A city stalled. New Zealand: The Press.

McGee, R. W. (2008). An economic and ethical analysis of the Katrina disaster. International Journal of Social Economics, 35(7), 546-557. https://doi.org/10.1108/03068290810886948

McGregor, D. G., Finucane, M., \& Gonzalez-Caban A. (2008). The effects of risk perception and adaptation on health and safety interventions. In W. E. Martin, C. Raish, \& B. Kent (Eds.), Wildfire Risk: Human Perceptions and Management Implications (pp. 142-155). Washington, DC: Resources for the Future Press.

Mitchell, R. K., Agle, B. R., \& Wood, D. J. (1997). Toward a theory of stakeholder identification and salience: Defining the principle of who and what really counts. Academy of Management Review, 22, 853-896.

Moricz, Z., Wong, C., \& Bond, S. (2012). The impacts of the Canterbury earthquake on the commercial office market. CBRE and Lincoln University.

Nappi-Choulet, I. (2006). The role and behaviour of commercial property investors and developers in French urban regeneration: The experience of the Paris region. Urban Studies, 43(9), 1511-1535. https://doi.org/10.1080/00420980600831692

Ohman, P., Söderberg, B., \& Westerdahl, S. (2013). Property investor behaviour: Qualitative analysis of a very large transaction. Journal of Property Investment \& Finance, 31(6), 522-544. https://doi.org/10.1108/JPIF-09-2012-0043

Olshansky, R. B., Johnson, L. A., \& Topping, K. C. (2006). Rebuilding communities following disaster: Lessons from Kobe and Los Angeles. Built Environment, 32(4), 354-374. https://doi.org/10.2148/benv.32.4.354

Ruwanpura, K. N. (2009). Putting houses in place: Rebuilding communities in post-tsunami Sri Lanka. Disasters 33(3), 436-456. https://doi.org/10.1111/j.1467-7717.2008.01082.x

Sellars, G. (2013). Property Council New Zealand market summit: The Rebuild. Colliers International.

Toomey, E. (2014). The slow road to recovery: A City rebuilds under the Canterbury earthquake Recovery Act 2011. Asia-pacific disaster management (pp. 217-243). Springer. https://doi.org/10.1007/978-3-642-39768-4_11

Waugh, J., \& Smith, R. B. (2006). Economic Development and Reconstruction on the Gulf after Katrina. Economic Development Quarterly, 20(3), 211-218. https://doi.org/10.1177/0891242406289287

Yin, R. K. (2003). Case study research: Design and methods (3rd ed., Vol. 5). California: Sage Publications.

\section{Copyrights}

Copyright for this article is retained by the author(s), with first publication rights granted to the journal.

This is an open-access article distributed under the terms and conditions of the Creative Commons Attribution license (http://creativecommons.org/licenses/by/4.0/). 